This item was submitted to Loughborough's Research Repository by the author.

Items in Figshare are protected by copyright, with all rights reserved, unless otherwise indicated.

New state spatialities: perspectives on state, space and scalar geographies

PLEASE CITE THE PUBLISHED VERSION

http://dx.doi.org/10.1111/j.1467-8330.2010.00792.x

PUBLISHER

Wiley (@ The authors)

VERSION

AM (Accepted Manuscript)

LICENCE

CC BY-NC-ND 4.0

REPOSITORY RECORD

Harrison, John, and Julie MacLeavy. 2019. "New State Spatialities: Perspectives on State, Space and Scalar Geographies”. figshare. https://hdl.handle.net/2134/6633. 
This item was submitted to Loughborough's Institutional Repository (https://dspace.lboro.ac.uk/) by the author and is made available under the following Creative Commons Licence conditions.

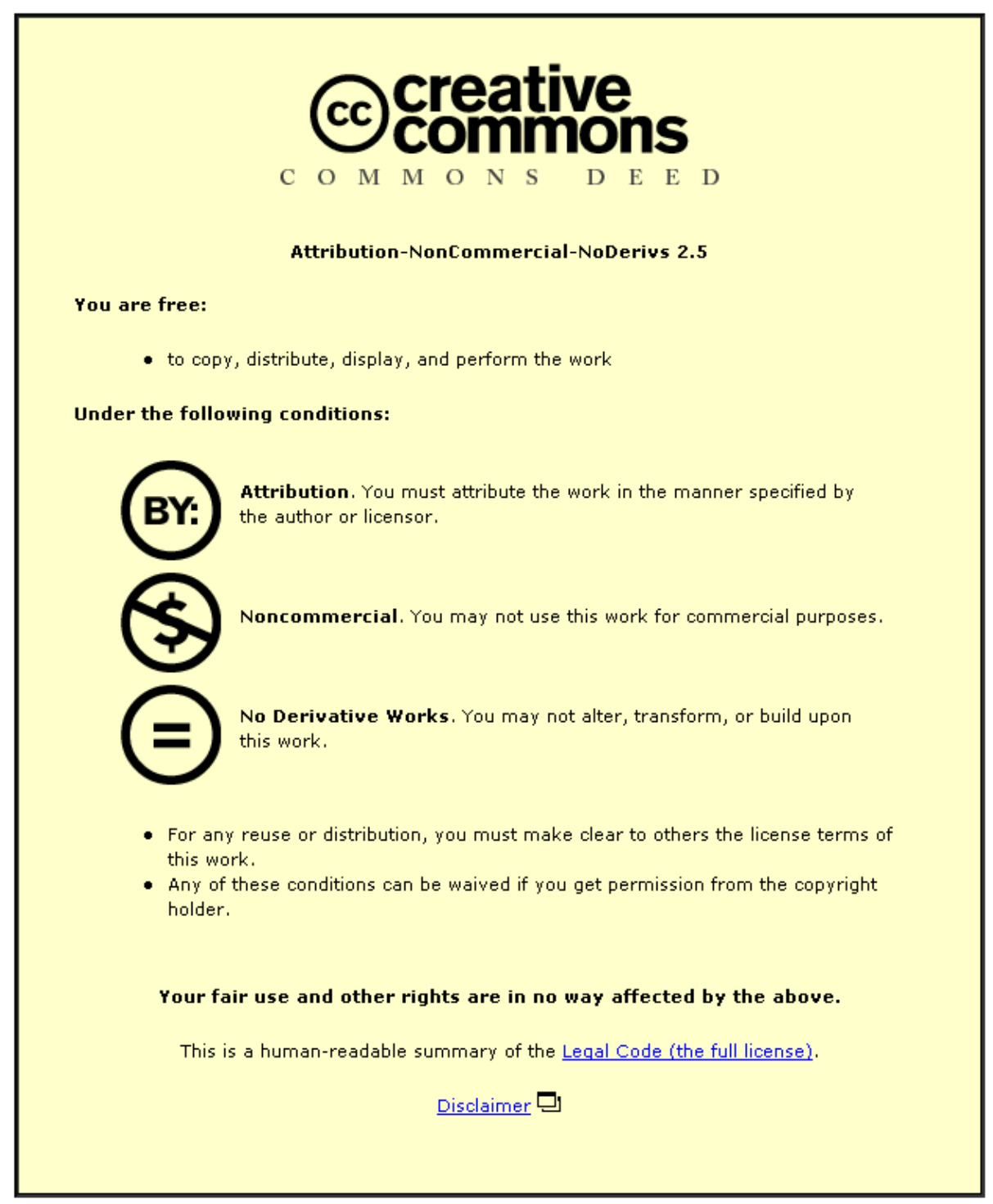

For the full text of this licence, please go to: http://creativecommons.org/licenses/by-nc-nd/2.5/ 
New State Spatialities:

Perspectives on State, Space, and Scalar Geographies

\author{
Julie MacLeavy \\ Department of Geography \\ University of Bristol \\ j.macleavy@bristol.ac.uk \\ John Harrison \\ Department of Geography \\ Loughborough University \\ j.harrison4@lboro.ac.uk
}

February 2009

In: Antipode 42(5) 


\section{New State Spatialities: Perspectives on State, Space, and Scalar Geographies}

In recent years there has been a resurgence of interest in states, space and scalar geographies. However, the unprecedented enthusiasm for the theorisation and research of 'new' state spaces (Brenner 2004) has been accompanied by an emergent scepticism towards this theoretical framing; specifically the apparent emphasis of a single dimension of socio-spatiality in (political-economic) geography scholarship. The analysis of state spatiality poses a number of challenges to contemporary socio-spatial theory, not least of which is the tendency to portray the state and its territorial structure as static and bounded. This conflicts with relational and compositional views of space, which decentre and destabilise categories of organising socio-economic life through a focus on actors, institutional structures and their interactive power relations. Re-orientating analytical attention away from the state as if it is causal and explanatory in its own right, this special issue instead investigates how relational geometries of state space are imbued with causal power capable of producing socio-economic change. In so-doing this special issue contributes to the development of theoretical approaches to the spatiality of the state in the critical sub-disciplines of geography, such as spatial political economy. It also speaks to ongoing debates in human geography more broadly about space, place, scale and network.

As an object of analysis, the state exists simultaneously as a material force and an ideological construct (Mitchell 2006). While the network of institutional arrangements and political practice that forms the material substance of the state is diffuse and ambiguously defined at its edges, the popular conception of the state as an ideological construct is more coherent. This presents a challenge for theorybuilding, because an overly rigid conception of the state - derived from the idea of the state as a free-standing entity - risks misrepresenting the incoherence of state practice, and its constitution in social and economic processes. Understanding the state idea as emergent from techniques that enable mundane practices to take on the appearance of an abstract non-material form permits us to view the terrain of the state as forged through ongoing engagements between agents, institutions and concrete political and policy circumstances. This identifies the state as a contingent development: changing over time and in different geographical contexts in accordance with social, economic and political circumstances.

Comprehending the development of new state spaces is consequently necessary to elucidate regulatory adjustment and advance geographical conceptions of the state. The spatial transformation of statehood amidst the current tremors of 
globalised capitalism re-orientates state institutions and policies towards the domestic economy (Harvey 2008; Wade 2008), illuminating political-territorial configurations as not pre-given or pre-formed, but historically created and reconstituted in a process of relative stability and continuous redefinition (cf. Brenner 2004). This is central to the understanding of the state as a site of interaction and/or negotiation. The characterisation of state spatiality as a conditional, contested and ultimately changeable modality through which territorial political power evolves prompts the reformulation of state theory to include actors entangled in actual power geometries and institutionalised spatial practices struggling over the meaning of space (Brenner et al. 2003). This complicates conceptions of state space as simple hierarchy and verticality by positing new state spaces as expressions of an actual politics of space (Jones and MacLeod 2004).

Through the examination of 'actually-existing' demonstrations of state policy and state evolution, the papers in this issue question and theorise the relationships between space, society and the territorialities of governing. In doing so, they engage with the salient interventions in human geography intended to denaturalise received terms and reveal the constructed and repeatedly reconstructed nature of taken-forgranted concepts such as state, space and scale in empirical research enquiries (see, for example, Brenner et al. 2003; Geografiska Annaler 2004). In particular, the papers confront critiques of the conceptualisation of state space as territorial or scalar through the careful articulation of approaches to state spatiality that build on the mobilisation of networks, topology and relationality as key analytical concepts in socio-spatial theory. In this sense the contributions here build on those of Sallie Marston, John Paul Jones III and Keith Woodward (2005), who have been vocal in their critique of the dominant hierarchical conception of scale that has tended to inform work interrogating the institutional terrains of the contemporary state (for example, the work of Neil Brenner (1998) and others positioned within New Regional Geography; (cf. Jonas 2006)); and, Helga Leitner and Byron Miller (2007) who express concern over the privileging of scale vis-à-vis other spatialities in geography and, while contending that the vast majority of research recognises the mutual constitution of structure and agency in political economy, argue for a further 'grounding' of conceptual arguments through the study of everyday practices and power relations. By opening up new sets of problematics around strategic flows, processes, connections, structures, agencies and institutions, one might posit that these debates around state, space and scalar geographies have served to produce a 'place' in which the ontological incommensurabilities within the discipline of human geography are being reconsidered. 
But it is not only the 'scale debate' that has impacted theorisations of state and space in geography recently. Doreen Massey (2004: 17) concludes her exploration of the geographies of identity and responsibility with the observation that "place can be a political project". Certainly, the construction of state, space and scale in human geography has important ramifications. The evaluation of specificity in geographical 'sites' (Marston et al. 2005) must therefore be weighed against a politics of bringing disparate spaces into a homogenous geographical imaginary. While the former enables an understanding of state space as a social category, produced and appropriated through the dynamics of social relations (Soja 1989), the latter positions state spatiality as a flexible heuristic for interpreting economic, political and cultural dimensions. Discussions of state, space and scale in geography in this sense entail theoretical considerations, as well as a continued negotiation of “conceptual positions and the demands of 'real' politics" (Massey 2004: 5).

This special issue is not a defence of the value of representing the spatiality of the state through the framework employed by Brenner and other strategicrelational state theorists. Nor even is it an attempt to police the ways in which we might use the terms 'state', 'space' and 'scale' in our research enquiries, although that is one evident response to the present confusion (see, for example, Sheppard and McMaster 2004). It does, however, presume that interventions by scale protagonists - or 'scalists' following Jonas (2006: 399) - and a number of engaged critics are significant and worthy of continued discussion and debate. Indeed, the range of perspectives on 'state spatiality' displayed through the papers in this special issue, we would argue, is indicative of the state of political-economic scholarship and its relevance across the spectrum of human geography today.

Over the past few decades, scholarship on state, space and scale has taken many forms. Once driven by the exploration of institutions and economic organisations that transgress the boundaries of nation-states, there is now greater appreciation of the production of scale through the extra-economic realm. Following the work of Erik Swyngedouw (1997) - and others - on the 'politics of scale', state spatiality is no longer conceived as a politically neutral container of social processes, or a methodological abstraction. Rather it is understood as the product of socioeconomic struggles and transformations (Newstead et al. 2004). In this respect, particular consolidations of territory, such as the formation of regional clusters, cities or nation-states have been seen as transient scalar fixes, which are always vulnerable to transformation by new rounds of capital (dis)investment, however concretised they seem (for example, Brenner 1997). 'Scale jumping' is the result of such changes affecting the territorial scope of power (Newstead et al. 2004). 
While claiming something distinctive, fresh calls for geographies of social reproduction and consumption (for example, Marston 2000) were indebted both to the conceptualisation of scale as the contingent outcome of tensions that exist between structural forces and the practices of human agents, and more recent (cultural) theorisations of scale as a site of power modalities. The positioning of scales as embedded in and related to socio-cultural processes and activities precipitated the differentiation of the horizontal organisation of scale from its vertical orientation (see Brenner 2001). Yet the strategic-relational and predominantly economic orientation of this work meant that there has been only limited acknowledgement of the capacity of feminist arguments to enhance the scale debate. Indeed, we might observe the interstice that remains between mainstream political economy approaches to state, space and scale and more recent investigations that have emerged from Sallie Marston and Neil Smith's (2001) work on the repositioning of scale as an 'embodied process' (for example, explorations of the body) or J-K Gibson-Graham's (2006) deconstruction of local community domains (i.e. the scale of social relations).

There are a range of other scholars - some geographers and others who have a geographical readership - whose work engages with the question of state spatiality but who (thus far) have not been incorporated into the intellectual lineages constructed for, or future agendas set by, state theory. The work of Manuel Castells (1996; 2000), for instance, is central to scholarship on networked and multilevel governance (for example, Bevir and Rhodes 2003; Braithwaite 2006; Rhodes 1997). In suggesting a global macro-sociology of the 'information age', in which networks are comprised of subjects and technologies and the links in between, this work provides for the (re)imagining of states as highly dynamic, open structures that are able to expand almost without limits. By pointing towards the 'statisation of society', this enables an epistemological break from older, structuralist accounts of the state. From a different direction, Michel Foucault's (1977 - 1978 [2007]) work on governmentality reverses this trajectory by forwarding an approach to state spatiality that is centred on the 'governmentalisation of the state' (cf. Lemke 2001; cf. Rose 1996). In pointing towards the blurring of 'spaces of freedom' and 'spaces of state', Foucault's work foregrounds questions pertaining to the origins of state power, its limits, and genealogical development. In this, the focus is not on state space per se, but on 'government' and the necessarily geographical production of governable spaces and subjects (Rose 1999).

Poststructuralist understandings of networks as a social form (see Knox et al. 2006) draw upon Actor Network Theory to provide further insights into how state 
spatialities are produced by social thought and action, filtered through state-spatial imaginaries (Collinge 2006; Moore 2008). John Law and Annemarie Mol (2001) point towards the potential of ideas pertaining to fluidities and thus the spatialities of 'conjoined alteration' (wherein there is no fixity only a 'shapeless' energy which encompasses the experiential, subjective and transience of state/space/scalar understanding). Again, this research is suggestive of a significantly different conception of state institutions (Leitner 2004) and state power geographies (Slaughter 2005) than those found in structuralist accounts.

In a similar vein, ethnographic and anthropological accounts of the state emphasise the ways in which state spaces are produced in the relational moment. State actors, in these accounts, are constituted by their relations: it is the spatialisation of those relations that constitutes what we might term state space. The model of 'network sociality' that is forwarded by Andreas Wittel (2001) illustrates one possible means of decentring (state) analysis through a transition from concepts of space/place (or placelessness) through an appreciation of mobility and the mobile. This is subtly different from the analyses that argue that scales and spaces are relationally constituted and change through their interaction with each other because it presumes that these do not pre-exist and therefore cannot be interacting.

\section{Structure of the Volume}

This special issue builds on these debates regarding the conceptualisation of state space as territorial or scalar, as well as networked, topological and relational. It confronts these matters through a series of empirical investigations of the production of new strategic sites/spaces in the geographies of capitalism in the present era. This allows for a clear indication of the difference made by new approaches to state, space and scalar geographies. It also attends to the political-economic context which provides for (and informs) contemporary human geographical problematics. The contributions to this volume were initially presented at the 2008 Annual Meeting of the Association of American Geographers in Boston. Here the problem of conceptualising state spatiality was considered in four sessions that critically assessed the value of representing the spatiality of the state through the scalar framework employed by Brenner (2004) and other strategic-relational theorists in light of debates around the conceptualisation of space and scale in human geography. Emerging out of these debates, and using a range of methodological approaches and empirical reference points, the following papers engage with state spatiality in (at least) three ways: (i) by developing theoretical frameworks through which to explore contemporary state spatiality; (ii) by analysing the spatial logics, 
dynamics and contradictions of state restructuring projects; and, (iii) by examining the political relevance of conceptual, theoretical, methodological and empirical discussions around state spaces. Thus, the volume is organised into three parts that reflect the contributors' efforts to advance new ways of conceptualising state spatiality.

Part 1 considers theoretical approaches to state spatiality that challenge or defend the foundations upon which the framework of 'new state spaces' (Brenner 2004) has been constructed. Nick Gill's paper considers the ontological status of the state itself and calls for a move beyond critical realist epistemology. Drawing on research with asylum seekers in the United Kingdom, Gill asserts that the state is visible not in territoriality but in the moment at which (fear of) the state becomes inscribed on the human body. On this basis, he advocates an anti-essentialist state theory as both an actually existing apparatus and an idea (which can possess more power than its institutional capabilities).

John Allen and Allan Cochrane instead pinpoint the conceptualisation of power as a means of deconstructing the vertical imagery of Brenner's (2004) geography of new state spaces. Allen and Cochrane's paper develops a topological interpretation of the assemblages of state power that implies that states possess 'reach', not 'height' as implied by a scalar ontology.

Building on this, Joe Painter investigates the potential compatibility of geographical understandings of territory and networks to develop a reading of state space as both territorial/scalar and relational/networked/topological (cf. Hudson 2007; MacLeod and Jones 2007; Morgan 2007). Painter argues that territory is a social effect, generated by and dependent upon networked practices. This contradicts traditional comprehension of the state as territorially bounded, revealing the historical context of theoretical understandings (in this case the understanding that emerged at a time when the nation state was afforded primacy as the site and/or scale at which economic management was conducted, social welfare delivered and at which political subjects were treated as national citizens).

The final paper in Part 1 sees Martin Jones and Bob Jessop revisit their earlier contributions to the theorisation of the territorial state, in particular the arguments made for polymorphy in socio-spatial theory in a recent paper with Brenner (Jessop et al. 2007). Jones and Jessop elucidate a 'compossible' view of state spatiality that considers how various possible, but mutually contradictory, spate spatialities can coexist. This, they argue, represents a major advance on the critical realist notion of contingent necessity, which is concerned primarily with abstraction. 
In contrast, they argue, the notion of compossibility prioritises a grounded examination of conjectural events and socio-spatial processes.

Part 2 explores the emergence and institutionalisation of state spaces through detailed consideration of state restructuring projects. The papers here underline the historically-embedded and path dependent nature of restructuring processes, whilst noting the tendency in strategic-relational analyses to overlook the complex politics associated with the transitions in the regulation and governance of contemporary capitalism. Stijn Oosterlynck's paper focuses on the geographical bases of power that secured the nationalisation of state space in the context of uneven regional development. From this, Oosterlynck asserts the relevance of political agency and political-hegemonic moments of regulatory and accumulation dynamics to the understanding of empirical variety in state spatiality.

In order to reveal the influence of past (political and environmental) legacies on contemporary efforts to restructure the political economy, Proinnsias Breathnach's paper considers the long-term spatialities of the state. Considering the historical spatiality of the Irish state, Breathnach argues that in instances where the prevailing (national) state apparatus is unable to countenance spatial selectivity in the allocation of resources and the devolution of administrative functions, a sustained period of economic crisis is necessary to mobilise social forces capable of precipitating state spatial restructuring. This signals the need to reflect on the nature and multiplicity of relations which compose contemporary political economies and their potential relationship to state rescaling processes.

In the final paper in Part 2, Jung Won Sonn calls for a more critical engagement with semiotic processes in discussions of state spatiality. Sonn's specific focus is on the discursive moment of strategies for steering rescaling processes. His analysis of the historical and geographical conditions that enabled the Roh administration to preserve state power in South Korea against pressure towards devolution positions the forces acting in and through the nation state as active agents of neoliberal state rescaling.

Part 3 of the special issue considers the implications of the current reconfiguration of state spaces, alongside the political relevance of scholarly understandings of changing geographies of governance. Danny MacKinnon and Jon Shaw's paper focuses on contingency and the particularity of the politics shaping governance geographies. MacKinnon and Shaw forward an account of the political tensions and conflicts over an emergent policy space that reveals contradictory impulses towards administrative decentralisation and centralisation in policy development. This, they argue, results in the national government exerting control 
over subnational actors and organisations through the formalisation of regional structures, which indicates that it is not scale per se that is the object of struggle in state restructuring, but rather specific processes and institutionalised practices which are themselves differently scaled (cf. Harrison 2008).

Krisztina Varro's paper identifies the ontological privileging of economic structures and the conceptualisation of politics in economic terms in strategic-relation approaches to the state. With reference to, and complementing, recent interventions around conceptualising city-regions as the product of a particular set of economic, political, social, and environmental logics, Varro highlights the need to re-politicise strategic-relational state theory such that new state spaces are not seen simply as an expression of a new era of capitalist development, but expressions of "an actual politics of and in space" (Ward and Jonas 2004: 2122).

The politics of conceptual, theoretical, methodological and empirical discussions around state spatiality is considered, more broadly, by Greig Charnock who in the final paper in Part 3 considers the relationship between Marxism as developed in the work of Henri Lefebvre and recent scholarship on new state spaces. In particular, Charnock critiques strategic-relation approaches to the state (and their attendant concern with the political-economy of scale) for a non-critical reading of Lefebvre. Revisiting Lefebvre's work on space, Charnock argues that strategicrelational approaches assume the permanence of capitalism to allow for the construction of generally applicable analytical frameworks, in a move that forecloses forms of thought (which Lefebvre's own work warns against).

It is our hope that the theoretical and methodological approaches developed in this volume will prove useful for scholars concerned with understanding new state spatialities. This volume brings together both familiar and emerging voices to provide an up-to-date account of the novel perspectives being used to develop fresh understandings of state space. Providing such a range of views allows for a clear indication of the difference made by new approaches to state, space and scalar geographies; serves to situate these debates within the broader contours of human geography and its cognate disciplines; and provides multiple paths of access for those wishing to familiarise themselves with this innovative area of geographical thought and practice.

\section{Acknowledgements}

We would like to thank Noel Castree and the Antipode editorial board for providing us with a medium in which to pursue this project. Special thanks are due to Noel and his editorial manager, Andrew Kent, for their guidance and clarity of instruction at every 
stage of this project. We are particularly grateful to Neil Brenner for encouraging us to pursue the project when we first pitched the idea of organising conference sessions around the framework of 'new state spaces', and to Mark Goodwin, Martin Jones and Keith Woodward who acted as discussants for the papers presented in Boston. Thanks are also due to the many referees who reviewed the papers for this special issue, for their speed in working to a tight timetable and their expertise in prompting contributors to strengthen their papers further. Finally, we are indebted to Martin Jones for his constant encouragement, insight, and guidance both in relation to this special issue and the previous research out of which this project developed.

\section{References}

Bevir M and Rhodes R A W (2003) Interpreting British Governance. London: Routledge

Braithwaite J (2006) Responsive Regulation and Developing Economies, World Development 34(5):884-898

Brenner N (1997) State Territorial Restructuring and the Production of Spatial Scale: Urban and Regional Planning in the Federal Republic of Germany, 19601990. Political Geography 16(4):273-306

--- (1998) Between Fixity and Motion: Space, Territory and Place in the Social Production of Spatial Scale. Environment and Planning D: Society and Space, 16(4):459-481

--- (2001) The Limits to Scale? Methodological Reflections on Scalar Structuration. Progress in Human Geography 25(4):591-614

--- (2004) New State Spaces - Urban Governance and the Rescaling of Statehood. Oxford: Oxford University Press

Brenner N, Jessop B Jones M and MacLeod G (eds.) (2003) State/Space: A Reader. Oxford: Blackwell

Castells M (1996) The Rise of the Network Society. Oxford: Blackwell

--- (2000) The Rise of the Network Society ( $2^{\text {nd }}$ edn.) Oxford: Blackwell

Collinge C (2006) Flat Ontology and the Deconstruction of Scale: A Response to Marston, Jones and Woodward. Transactions of the Institute of British Geographers 31(2): 244-251

Foucault M (2007) Security, Territory, Population: Lectures at the College De France, 1977-1978. Basingstoke: Palgrave Macmillan

Geografiska Annaler (2004) The Vega Symposium, Geografiska Annaler Series B Human Geography 86(1):1-78

Gibson-Graham J-K (2006) A Postcapitalist Politics. London: University of Minnesota Press.

Harrison J (2008) Stating the Production of Scales: Centrally Orchestrated Regionalism, Regionally Orchestrated Centralism. International Journal of Urban and Regional Research 32(4):922-941

Harvey D (2008) The Right to the City. New Left Review 53:23-40

Hudson R (2007) Regions and Regional Uneven Development Forever? Some Reflective Comments Upon Theory and Practice. Regional Studies 41(9):1149-1160

Jessop B Brenner N and Jones M (2007) Theorizing Socio-Spatial Relations. Environment and Planning D: Society and Space 26:389-401. 
Jonas A E G (2006) Pro Scale: Further Reflections on the 'Scale Debate' in Human Geography, Transactions of the Institute of British Geographers 31(3):399406.

Jones III J P Woodward K and Marston S A (2007) Situating Flatness: A Reply. Transactions of the Institute of British Geographers 32(2):264-276.

Jones M and MacLeod G (2004) Regional Spaces, Spaces of Regionalism: Territory, Insurgent Politics, and the English Question. Transactions of the Institute of British Geographers 29(4):433-452

Knox H Savage M and Harvey P (2006) Social Networks and the Study of Relations: Networks as Method, Metaphor and Form. Economy and Society 35(1):113140

Law J and Mol A (2001) Situating Technoscience: An Inquiry into Spatialities. Environment and Planning D: Society and Space 19:609-621.

Leitner H (2004) The Politics of Scale and Networks of Spatial Connectivity: Transnational Interurban Networks and the Rescaling of Political Governance in Europe. In Sheppard E and McMaster B (eds) Scale and Geographical Inquiry: Nature, Society and Method (pp. 236-255). Oxford: Blackwell

Leitner H and Miller B (2007) Scale and the Limitations of Ontological Debate: A Commentary on Marston, Jones and Woodward. Transactions of the Institute of British Geographers 32(1):116-125.

Lemke, T (2001) The Birth of Bio-Politics: Michael Foucault's Lecture at the College de France on Neoliberal Governmentality. Economy and Society 30(2):190207

MacLeod G and Jones M (2007) Territorial, Scalar, Networked, Connected: In What Sense a 'Regional World'? Regional Studies 41(9):1177-1191.

Marston, S A (2000) The Social Construction of Scale. Progress in Human Geography 24(2):219-242

Marston S A Jones III J P and Woodward K (2005) Human Geography Without Scale. Transactions of the Institute of British Geographers 30(4):416-432

Marston, S A and Smith N (2001) States, Scales and Households: Limits to Scale Thinking? A Response to Brenner. Progress in Human Geography 25(4):615619

Massey D (2004) Geographies of Responsibility. Geografiska Annaler: Series B, Human Geography 86(1):5-18

Mitchell T (2006) Society, Economy and the State Effect. In Sharma A and Gupta A (eds.) The Anthropology of the State (pp. 169-186). Oxford: Blackwell

Moore A (2008) Rethinking Scale as a Geographical Category: From Analysis to Practice. Progress in Human Geography 32(2):203-225

Morgan K (2007) The Polycentric State: New Spaces of Empowerment and Engagement? Regional Studies 41(9):1237-1251

Newstead C Reid C and Sparke M (2004) The Cultural Geography of Scale. In Anderson K Domosh M Pile S and Thrift N (eds.) Handbook of Cultural Geography (pp. 485-497). London: Sage

Rhodes R A W (1997) Understanding Governance. Buckingham: Open University Press

Rose N (1996) Governing 'Advanced' Liberal Democracies. In Barry A Osborne T and Rose N (eds.) Foucault and Political Reason (pp. 37-64). London: University College of London Press

--- (1999) Powers of Freedom: Reframing Political Thought. Cambridge: Cambridge University Press

Sheppard E and McMaster B (eds) (2004) Scale and Geographical Enquiry: Nature, Society and Method. Oxford: Blackwell

Slaughter A (2005) A New World Order. Princeton, NJ: Princeton University Press

Soja E (1989) Postmodern Geographies: The Reassertion of Space in Critical Social Theory. London: Verso 
Swyngedouw E (1997) Neither Global nor Local: 'Glocalization' and the Politics of Scale. In Cox K (ed.) Spaces of Globalization (pp. 137-166). New York: Guilford Press

Wade R (2008) Financial Regime Change? New Left Review 53:5-21

Ward K and Jonas A E G (2004) Competitive City-Regionalism as a Politics of Space: A Critical Reinterpretation of the New Regionalism. Environment and Planning A 36(12):2119-2139

Wittel, Andreas (2001) Towards a Network Sociality. Theory, Culture and Society 18(6):51-76 